International Journal of Social Sciences and Humanities
Available online at http://sciencescholar.us/journal/index.php/ijssh
Vol. 3 No. 2, August 2019, pages: 208 216
e-ISSN: 2550-7001, p-ISSN: 2550-701X
https://doi.org/10.29332/ijssh.v3n2.316

\title{
Causative Constructions in the Language of Nias
}

\author{
Wa'özisökhi Nazara a ${ }^{a}$ I Nengah Sudipa ${ }^{b}$, Ketut Artawa ${ }^{c}$, Made Sri Satyawati ${ }^{d}$ \\ Article history: Received 27 December 2018, Accepted: 30 April 2019, Published: 18 August 2019
}

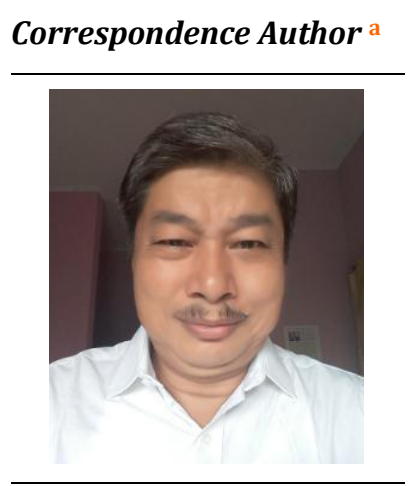

Keywords

construction; morpholexical; operation; prefix; suffix;

\begin{abstract}
This is a brief analysis of causative constructions in Nias, an Austronesian language spoken by around 813,155 people on the island of Nias of the west coast of Sumatera in Indonesia. It specifically deals with the strategies employed in constructing causatives in the verb-initial language. Data were obtained from Nias-speaking informants living in Laowöwaga, one of the villages in the district of East Lahewa in the reference of North Nias. The results of the analysis show that causatives in the language of Nias are constructed through morpholexical operation involving affixes and words/pre-categrorials. More specifically, some causatives are formed by attaching prefix $\{\mathrm{fe}-\}$ or its allomorph $\{\mathrm{f}-\}$ to an intransitive verb. Some are formed by morpholexical operation involving suffix $\{-0 ̈\}$ and an adjective or suffix $\{$-gö $\}$ and a precategorial. Both morpholexical operations involving prefix and those involving suffix and the base introduce direct causers. Some causatives are formed by attaching confix $\{$ fa-...-ö $\}$ to a transitive verb as the base. This morpholexical operation changes the argument function introduced from direct causer to indirect causer.
\end{abstract}

e-ISSN: 2550-7001, $p$-ISSN: 2550-701X ${ }^{\odot}$ Copyright 2019. The Author. SS Journals Published by Universidad Técnica de Manabí. This is an open-access article under the CC BY-SA 4.0 license (https://creativecommons.org/licenses/by-sa/4.0/) All rights reserved.

\section{Contents}

Abstract

1. Introduction

2. Materials and Methods

3. Results and Discussions

3.1 A Brief Overview of Causatives

3.2 Causative Constructions in Nias.

4. Conclusion

a STBA Prayoga, Padang, Indonesia

b Udayana University, Denpasar, Indonesia

c Udayana University, Denpasar, Indonesia

d Udayana University, Denpasar, Indonesia 


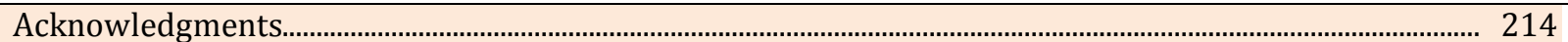

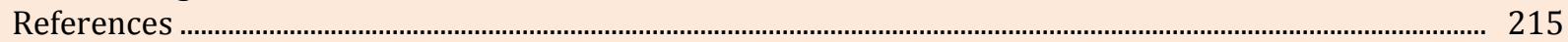

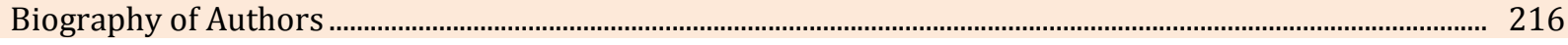

\section{Introduction}

It is generally acknowledged that causative constructions have been one of the interesting topics in linguistics recently. This is due to the assumption that the analysis of causative constructions involves not only the semantic structure but also syntactic expression. More specifically, causative constructions have to do not only with morphosyntactic processes; they also have to do with morphosemantic processes (Hemings, 2013).

More detailed argumentation highlighting the importance of causative constructions as a current topic for linguists to address has been set out by Kroeger (2004). The linguist considers that causative constructions are of paramount importance for a number of reasons. One of the considerations is that causative constructions reveal morphological, syntactic, and semantic relationships. The second reason is that causatives indicate the independence of phrase structure, functional structure, and argument structure. The third reason is that causative constructions contribute positively to linguistic research across languages.

As implied by its title, this short paper discusses causative constructions in the language of Nias. It specifically addresses the forms and functions of causative constructions in the language. The forms and functions cover causativization by prefixes, causativization by suffixes, and causativization by confixes.

\section{Materials and Methods}

This study is qualitative in nature. In this research, the researcher functioned as the key instrument and the data obtained and analyzed were qualitative. It was data-driven, with an inductive approach. Through this qualitative inquiry, the author sheds some lights on the forms and functions of causatives in the language of Nias. The data were mainly obtained from the native speakers of the north variety of the language of Nias. The informants are those speakers meeting criteria having to do with linguistic competence and age of the informants, their physical and psychological conditions, and their knowledge of the subject matters (Samarin, 1988; Mahsun, 2017; Bungin, 2017).

Data analyzed were obtained from the speakers of the north variety of the language of Nias as well as from written texts, through observation, interview, and introspection. Observation involved listening to some sentences which informants uttered and looking at some sentences in some books and articles as well as taking notes by the author. The interview included asking questions and elicitating the data by the author. Introspection involved creating and writing the data by the author as the native speaker of the language of Nias (Creswell, 2009; Cruz-Ferreira \& Abraham, 2011; Mahsun 2017).

The data collected through observation, interview, and introspection were analyzed through the qualitative procedure. At this stage, the author simplified and organized the data in such a way, in line with the research questions. Simplified and organized data were analyzed further using several relevant techniques, such as substitution, transposition, extension, and deletion (Sudaryanto, 2015; Mahsun, 2017; Udayana, 2016). These analyses resulted in a linguistic description of the causatives in the language of Nias.

\section{Results and Discussions}

\subsection{A Brief Overview of Causatives}

It goes without saying that some linguists have encapsulated definitions of causatives. Trask (1993), for instance, defines causatives in two ways: as constructions and as words. In terms of constructions, causatives are defined as transitive constructions, those having to do with transitive constructions or the second intransitive and simpler, characterized by the presence of noun phrase functioning as the agent. The noun

Nazara, W., Sudipa, I. N., Artawa, K., \& Satyawati, M. S. (2019). Causative constructions in the language of nias. International Journal of Social Sciences and Humanities, 3(2), 208-216. https://doi.org/10.29332/ijssh.v3n2.316 
phrases functioning as the agent are understood as the causer of the action expressed in the simpler construction. Some examples adapted from Trask (1993), are presented as (1) and (2) below.

(1) a. John smiles a lot.

b. Mark makes John smiles a lot.

(2) a. We washed the car.

b. Jane made us wash the car.

c. Jane had us washed the car.

d. Jane got us to wash the car.

Sentences (1a) and (2a) are both declarative sentences. Sentence (1a) is an intransitive sentence whilst sentence (2a) is a transitive sentence. Sentence (1a), whose predicate is an intransitive verb, describes one event. The single event described by the sentence involves a single argument. Sentence (2a), whose predicate is a transitive verb, also describes an event. However, the sentence (2a) involves two arguments. One of the two arguments is we and the other one is the car.

Sentences (1b) and (2b-d) are sentences with causative constructions. In sentence (1b) appears a causative verb and a noun phrase which becomes the causer of the event described by the sentence. The same phenomena are found in sentences (2b-d). Sentence (2a), for instance, has the causative verb made and the noun phrase Jane, that becomes the causer of the event to occur.

A similar definition of causatives has come from Kroeger (2004). According to Kroeger, causative constructions refer to sentence constructions which express some situation where one event causes another event. This means that in a causative construction there is a causer and a causee. Such a situation can be seen in the sentence (3), adapted from Kroeger (2004), like the following.

(3) a. Our dog died.

b. The man caused our dog to die.

c. The man killed our dog.

There is no doubt that the sentence (3a) is a simple sentence. It only consists of an independent clause. The sentence, which comprises of a single independent clause, is constituted by the intransitive verb die as the predicate and a single argument in the form of the noun phrase our dog. Unlike sentence (3a), sentence (3b) consists of two clauses. One of the two clauses is the one with the verb caused. This clause refers to the event caused by the participant the man. The other clause is the one with the verb die. This clause expresses the event which is the same as that expressed by sentence (3a). Note that even though the event expressed by the first clause differs from the one expressed by the second clause, there is a logical connection between the two events. The logical connection refers to a connection between cause and result. The event expressed by the first clause causes the event expressed by the second clause.

Unlike sentence (3b), which comprise two clauses, sentence (3c) is constituted by a single clause. The sentence consisting of one clause and the one composed of two clauses have a similar meaning. However, they are different concerning the causer of the event expressed by each of the sentences. In sentence (3b), participant the man is the indirect causer of the death whilst the participant the man in the sentence (3c) is the direct causer of the death.

As a matter of fact, a causative construction can be a sentence constituted by a clause, like (3c). However, it can also consist of two clauses, like the one shown by sentence (3b). At a glance, a causative construction composed of a single clause looks like a simple sentence with an adverbial clause whilst a causative construction looks like a complex sentence. In spite of such a fuzzy appearance, a causative construction differs either from a simple sentence with adverbial or a complex sentence. A causative construction differs from a complex sentence in that the causing effect in a causative construction is not overtly identified. Meanwhile, the difference between a causative construction and a simple sentence with an adverbial lies in the fact that the causing event, which is not overtly expressed in a causative construction, is implied in the core argument. Sentences adapted from Malấ (2012), which are presented as (4) below, clarify the difference. 
(4) a. Everybody was delighted because Anna started playing one of Chopin's waltzes.

b. Everybody was delighted because of Anna's playing.

c. Anna made everybody dance.

In the complex sentence (4a), both causing event and resulting event are overtly expressed: The causing event is expressed by subordinate clause because Anna started playing one of Chopin's waltzes; the resulting event is expressed by the main clause everybody was delighted. In the simple sentence (4b), the causing event is expressed by the adverbial because of Anna's playing. In the causative construction (4c), the causing event is not overtly specified; rather, it is implied within the core argument Anna.

Causative constructions, which at a glimpse look like a simple sentence with adverbial or look similar to a complex sentence, can be categorized into three types. The three types are lexical causatives, morphological causatives, and syntactic causatives (Comrie, 1989; Song, 1990; Kroeger, 2004; Malấ, 2012). Lexical causatives refer to the verbs whose meaning of cause is already inherent within the basic meaning of the verbs. The verbs kill 'cause to die', feed 'cause to eat', and inform 'cause to know' are three verbs of lexical causatives frequently cited in English. Morphological causatives are those where the verbs which express the resulting event undergo a certain morphological change. The morphological change adds the meaning of causing the event to the verbs undergoing the morphological change. The morphological change involves a free morpheme and a bound morpheme. The verb, femanga 'cause to eat', for instance, is the causative verb resulting from the bound morpheme prefix $\{\mathrm{fe}-\}$ attached to the verb manga 'eat'.

\subsection{Causative Constructions in Nias}

The language of Nias is rich in affixes. Some of the affixes play important roles in forming causatives in the language. As a matter of fact, causatives in this language are the results of morpholexical processes. The morphological processes involve some affixes (bound morphemes) and words (free morphemes). The causatives fall into three categories. The first category is the causatives formed by morpholexical processes involving prefixes and words functioning as the bases. The second one is the causatives formed by morpholexical processes which involve suffixes and words which function as the bases. The third category is the causatives which are formed by morpholexical processes involving confixes and words functioning as the bases. Explication of each of these three categories will respectively be presented below.

\section{a) Causatives Formed by Prefixation}

Causative verbs in the language of Nias can be formed by attaching prefix $\{$ fe- $\}$ to the verbs such manga 'eat', mondri 'take a bath', and mörö 'sleep'. These verbs are without affixes, can be seen in (5a), (6a), and (7a). The causative verbs resulted from morpholexical operation involving prefix $\{\mathrm{fe}-\}$ and the intransitive verbs without affixes can be observed in (5b), (6b), and (7b) respectively.

(5) a. Manga Dolamanö.

eat MUT.NAME

'Tolamanö eats.'

b. I-fe-manga Dolamanö Töngöni.

3SG-CAU-eat MUT.NAME NAME

'Töngöni feeds Tolamanö.'

(6) a. Mondri n-akhi-gu.

take a bath MUT-younger brother/sister-POSS.1SG

'My younger brother/sister takes a bath.'

b. u-fe-mondri n-akhi-gu.

1SG-CAU-bathe MUT-younger brother/sister-POSS.1SG

'I bathe my younger brother/sister.'

(7) a. Mörö n-ono da'a.

sleep MUT-child this

'This child sleeps.'

Nazara, W., Sudipa, I. N., Artawa, K., \& Satyawati, M. S. (2019). Causative constructions in the language of nias. International Journal of Social Sciences and Humanities, 3(2), 208-216. https://doi.org/10.29332/ijssh.v3n2.316 


\section{b. U-fe-mörö n-ono da'a. \\ 1SG-CAU-sleep MUT-child this \\ 'I make this child sleep.'}

Morpholexical operation involving prefix $\{\mathrm{fe}-\}$ and the intransitive verbs without affixes as in (5b), (6b), and (7b) raises the presence of the argument representing the direct causer of the event expressed by the verb. The argument raised by morpholexical operation is responsible for the event expressed by the verb functions as the subject, whilst the argument representing the causee occupies the object position. The presence of the argument functioning as the object in the causative construction reveals that the verbs resulted from the morpholexical operation by attaching prefix $\{\mathrm{fe}-\}$ to the intransitive verbs without affixes are bivalent, transitive verbs.

If the intransitive verbs to which prefix $\{\mathrm{fe}-\}$ is attached begin with vowels, the vowel /e/ of the prefix $\{\mathrm{fe}\}$ is dropped, leaving the consonant /f/ alone with the verbs. Two examples of intransitive verbs beginning with vowels can be observed in (8a) and (9a). The causative verbs resulting from the morpholexical operation involving $\{\mathrm{f}-\mathrm{\}}$ as the allomorph of prefix $\{\mathrm{fe}-\}$ and the intransitive verbs beginning with vowels can be seen in $(8 b)$ and $(9 b)$.

(8) a. Alua walöwa mahemolu. occur festival tomorrow

'The festival occurs tomorrow.'

b. Ma-f-alua walöwa mahemolu.

1PLEx-CAU-occur festival tomorrow

'We hold the festival tomorrow.'

(9) a. Elungu niha da'ö.

Get lost MUT.person that

'The person gets lost.'

b. I-f-elungu niha da'ö akhi-da.

3SG-CAU-get lost MUT.person that younger brother/sister-POSS.1PLIn

'Our younger brother/sister makes the person get lost.'

If the intransitive verbs with prefix \{mo-\}, the /f/ as the allomorph of prefix $\{\mathrm{fe}-\}$ replaces /m/ of prefix $\{\mathrm{mo}-\}$, to make the verbs causative verbs. An example of intransitive verbs with prefix $\{\mathrm{mo}-\}$ can be observed in (10a); the causative verb resulted from the morpholexical operation involving /f/ replacing / $\mathrm{m} /$ of the prefix $\{$ mo- $\}$ can seen in $(10 \mathrm{~b})$.
a. Mo-bawi N-ama Sofi.
Have-pig MUT-NAME
'Ama Sofi has pigs.'
b. I-fo-bawi
3SG-CAU-have pig
N-ama Sofi
Ama Wise.
'Ama Wise makes Ama Sofi have pigs.'

\section{b) Causatives Formed by Suffixation}

Causative verbs in the language of Nias can result from morpholexical operation involving suffix $\{-0 ̈\}$ and an adjective. Causative verbs formed in this way are transitive verbs. An example of adjectives from which causative verbs can be formed through the operation can be seen in (11a). The causative verbs resulted from the operation can be observed in (11b).
(11)
a. Alawa g-öli nowi.
tall MUT-fence field.
'The field fence is tall.'
b. I-alawa-ö g-öli nowi Töngöni.
3SG-tall-CAU MUT-fence field NAME


'Töngöni makes the field fence tall.'

Causative verb, which is transitive as the result of the morpholexical operation involving suffix $\{-0$ \} and the adjective alawa 'tall' brings two implications. One of the implications has to do with the noun phrase göli nowi 'fence of the field'. The same forms of noun phrase both in (11a) and (11b) are mutated. However, the noun phrase göli nowi 'fence of the field' in (11a) and that in (11b) occupy different grammatical functions. The NP göli nowi 'fence of the field' (11a) functions as the subject whilst the NP göli nowi 'fence of the field' functions as the object. The second implication of attaching causative prefix $\{-0$ \} to the adjective is that the direct cause of the event or condition expressed by the causative verb. The direct cause form Töngöni functions as the subject.

Morpholexical operation involving suffix $\{$-gö $\}$ and pre-categorials can also form causative verbs. The causative formed by attaching suffix \{-gö\} to pre-categorials are transitive verbs. An example of causative transitive verbs formed in this way can be seen in (12).

(12) I-hani-gö g-eu $\quad$ Töngöni.
3SG-drift-CAU MUT-wood NAME
'Töngöni make the wood drifted.'

The pre-categorials to which suffix \{-gö\} can be attached to form causative verbs are hono, höndrö, and hani. Attaching the prefix $\{\mathrm{a}-\}$ to these pre-categorials forms words ahono 'silent/calm', ahöndrö 'drowned', and ahani 'drifted'. Causative verbs honogö 'make silent/calm', höndrögö 'make drowned', and hanigö 'make drifted' are from morpholexical operation where suffix $\{$-gö $\}$ is attached to the pre-categorials in question.

\section{c) Causatives Formed by Confixation}

Confix $\{$ fa-...-ö $\}$ can be attached to the verbs such as fahö 'stab', halö 'take', and sura 'write' to form causative verbs. These bases are verbs without affixes. They are transitive verbs, subcategorizing two arguments. Two examples of the causative verbs formed in this way can be seen in (13b) and (14b). Their corresponding noncausative verbs can be observed in (13a) and (14a) respectively.

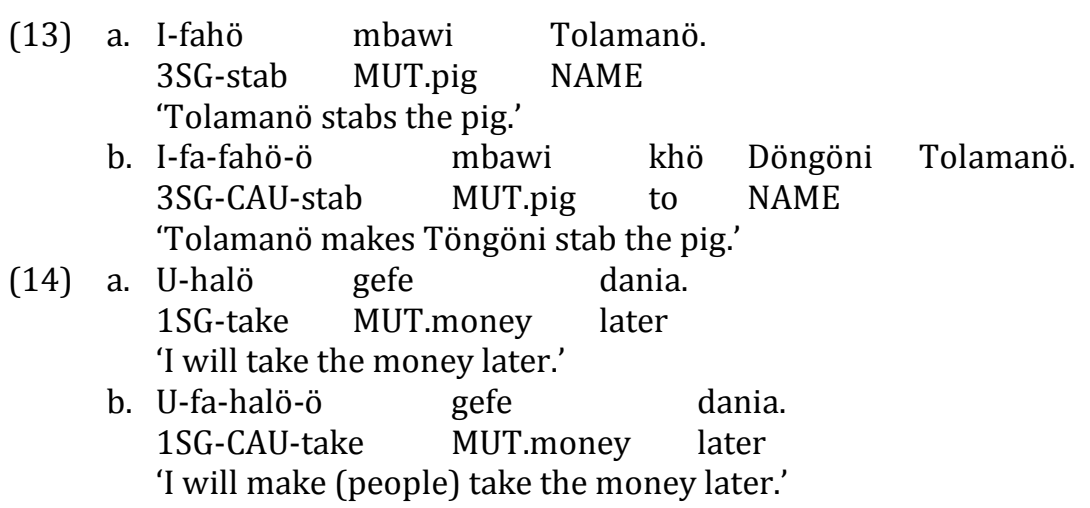

The causative verbs fafahö'ö and fahalö'ö as the result of morpholexical operation where causative confixes are attached to transitive verbs do not change the grammatical functions of their arguments. The arguments which function as the subjects in the sentences whose predicates are not causative verbs, like (13a) and (14a), remain to occupy the same functions in the corresponding sentences whose predicates are causative verbs, like (13b) and (14b). However, the roles of the arguments change. In (13a) and (14a), the arguments functioning as the subjects are the direct causes of the events, whilst in (13b) and (14b) the arguments are indirect causer. The morpholexical operation involving confix $\{\mathrm{fa}-. . .-0$ o $\}$ results in the introduction of the new cause of the event expressed by the causative verb as the predicate.

Nazara, W., Sudipa, I. N., Artawa, K., \& Satyawati, M. S. (2019). Causative constructions in the language of nias. International Journal of Social Sciences and Humanities, 3(2), 208-216. https://doi.org/10.29332/ijssh.v3n2.316 


\section{Conclusion}

Causative constructions in the language of Nias are formed by affixation. One of the affixes involved is prefix $\{\mathrm{fe}-\}$ and its allomorph $\{\mathrm{f}-\}$. Prefix $\{\mathrm{fe}-\}$ is attached to the verbs without affixes, such as mondi or mörö, or the $\{\mathrm{f}-\}$ as the allomorph of $\{\mathrm{fe}-\}$ is attached to the verbs with affix such as mobawi or mokefe, to constitute causative verbs. The other morpholexical operation which results in causative verbs involves suffixes $\{-0$ \} $\}$ and an adjective or suffix $\{$-gö $\}$ and a pre-categorial. Still, the other strategy is by attaching confix $\{$ fa-...-ö $\}$ a transitive verb. In conclusion, causative constructions in the language of Nias are the results of the morpholexical operation involving prefix, suffix, or confix and the base.

\section{Acknowledgments}

The authors would like to thank the editor of IJSSH for her valuable time, support, and advice in completing the current study. 
References

Bungin, B. (2017). Metodologi Penelitian Kualitatif: Aktualisasi Metodologis ke Arah Ragam Varian Kontemporer. Depok: Rajawali Pers.

Comrie, B. (1989). Language universals and linguistic typology: Syntax and morphology. University of Chicago press.

Creswell, J. W., \& Creswell, J. D. (2017). Research design: Qualitative, quantitative, and mixed methods approaches. Sage publications.

Cruz-Ferreira, M., \& Abraham, S. A. (2011). The language of language: A linguistics course for starters. CreateSpace.

Hemmings, C. (2013). Causatives and applicatives: The case for polysemy in Javanese. Working Papers in Linguistics, 16, 167-194.

Kroeger, P. (2004). Analyzing syntax: A lexical-functional approach. Cambridge University Press.

Mahsun. (2017). Metode Penelitian Bahasa: Tahapan Strategi, Metode, dan Tekniknya (3 ${ }^{\text {rd }}$ ed.). Depok: Rajawali Pers.

Malấ, M. (2012). English Causative Constructions with the Verbs have, get, and make, and their Czech translation Counterparts. https://dspace.cuni.cz/bit-stream/handle/-20.500.11956/42425/BPTX_2010_1_0274853_0_93126.pdf?sequence-1 (Downloaded on 7 November 2018).

Samarin, W. J. (1988). Creating language and community in pidginization. Canadian Journal of Linguistics/Revue canadienne de linguistique, 33(2), $155-165$. https://doi.org/10.1017/S0008413100012822

Song, J. J. (1990). On the rise of causative affixes: A universal-typological perspective. Lingua, 82(2-3), 151200.

Sudaryanto, D. P. (2015). Metode dan aneka teknik analisis Bahasa [Method and technique of language study].

Trask, R. L. (2013). A dictionary of grammatical terms in linguistics. Routledge.

Udayana, I. N. (2016). Effective sentences in Indonesian. International Journal of Linguistics, Literature and Culture, 2(2), 188-200.

Nazara, W., Sudipa, I. N., Artawa, K., \& Satyawati, M. S. (2019). Causative constructions in the language of nias. International Journal of Social Sciences and Humanities, 3(2), 208-216. https://doi.org/10.29332/ijssh.v3n2.316 


\section{Biography of Authors}

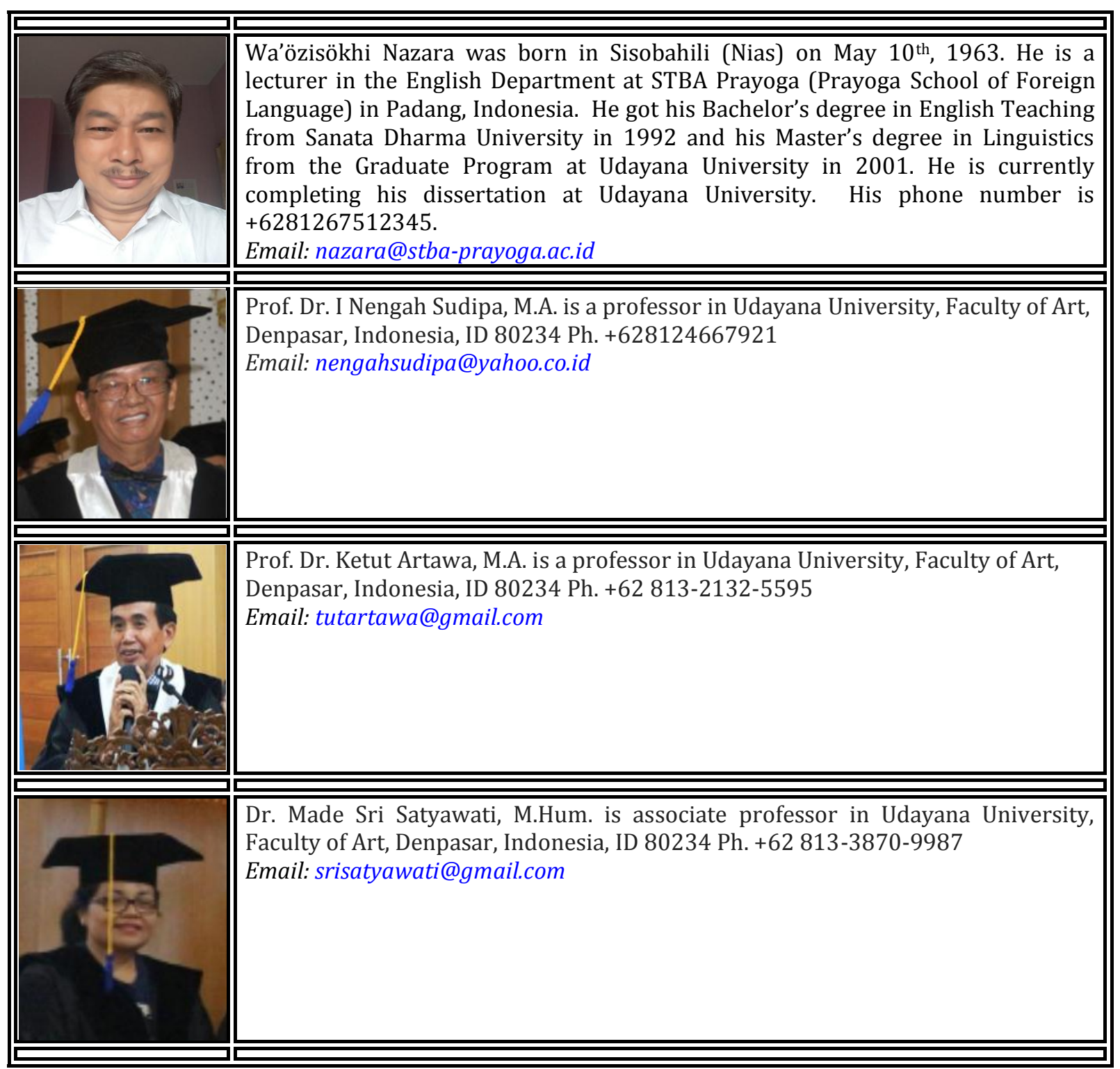

